\title{
Exclusive breastfeeding duration and determinants among Brazilian children under two years of age
}

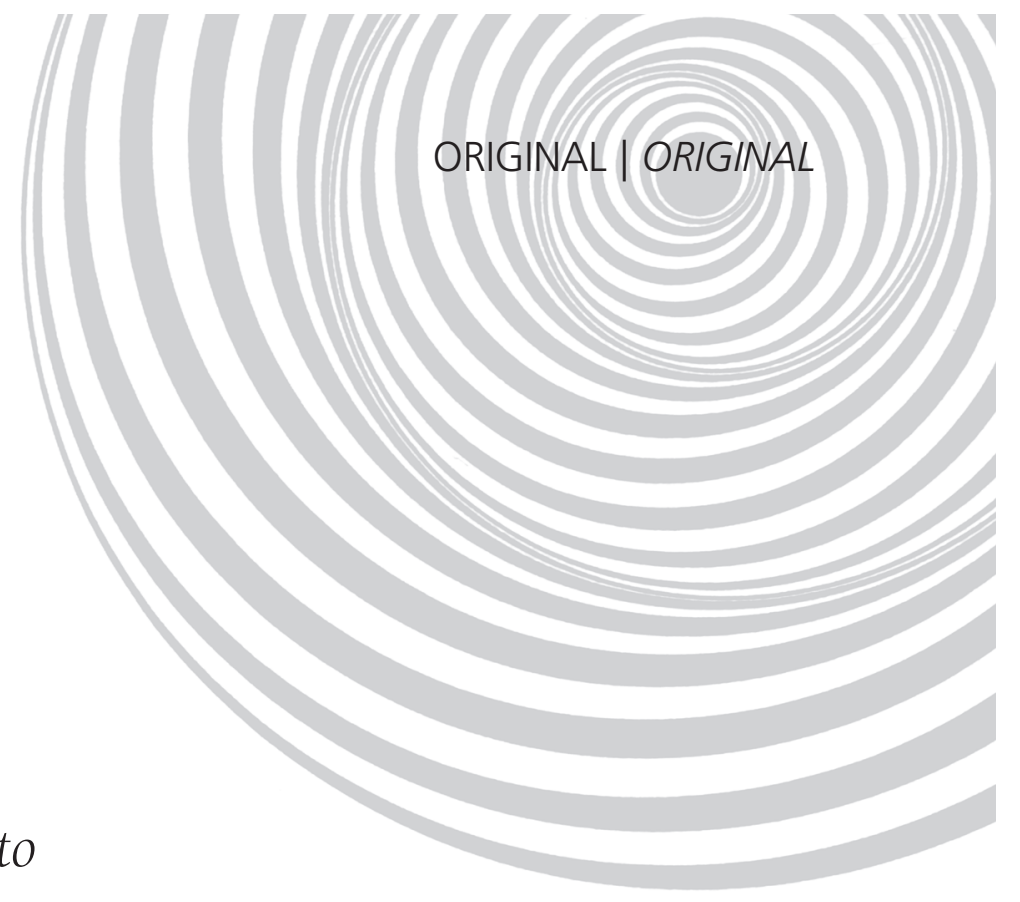

\section{Duração e determinantes do aleitamento \\ materno exclusivo entre crianças}

brasileiras menores de dois anos

\author{
Sarah WARKENTIN ${ }^{1}$ \\ José Augusto de Aguiar Carrazedo TADDEI ${ }^{1}$ \\ Kelly de Jesus VIANA ${ }^{1}$ \\ Fernando Antonio Basile COLUGNATI
}

A B S T R A C T

\section{Objective}

The present study described the duration and identified the determinants of exclusive breastfeeding.

\section{Methods}

The study used data from the Pesquisa Nacional de Demografia e Saúde da Criança e da Mulher 2006 (National Demographic and Health Survey on Women and Children 2006). Data were collected using questionnaires administered by trained professionals and refer to a subsample of 1,704 children aged less than 24 months. The estimated durations of exclusive breastfeeding are presented according to socioeconomic, demographic and epidemiological variables. Kaplan Meier estimator curves were used to produce valid estimates of breastfeeding duration and the Cox's proportional hazards model was fitted to identify risks.

\section{Results}

The median estimated duration of exclusive breastfeeding was 60 days. The final Cox model consisted of mother's age $<20$ years (hazard ratio $=1.53,95 \%$ confidence interval=1.11-1.48), use of pacifier (hazard ratio $=1.53,95 \%$ confidence interval $=1.37-1.71$ ), not residing in the country's southeast region (hazard ratio $=1.22,95 \%$ confidence interval $=1.07-1.40$ ) and socioeconomic status (hazard ratio $=1.28,95 \%$ confidence interval=1.06-1.55).

\section{Conclusion}

The Kaplan Meier estimator corrected the underestimated duration of breastfeeding in the country when calculated by the current status methodology. Despite the national efforts done in the last decades to promote

\footnotetext{
1 Universidade Federal de São Paulo, Escola Paulista de Medicina, Departamento de Nutrologia. R. Loefgreen, 1647 04040-032, São Paulo, SP, Brasil. Correspondência para/Correspondence to: S WARKENTIN. E-mail: <sarah_war@hotmail.com>.

2 Universidade Federal de Juiz de Fora, Faculdade de Medicina. Juiz de Fora, MG, Brasil.
} 
260 | S WARKENTIN et al.

breastfeeding, the results indicate that the duration of exclusive breastfeeding is still half of that recommended for this dietary practice to promote health. Ways to revert this situation would be ongoing educational activities involving the educational and health systems, associated with advertising campaigns on television and radio mainly targeting young mothers with low education level and low income, identified as those at high risk of weaning their children early.

Indexing terms: Breast feeding. Health surveys. Infant. Risk factors. Survival analysis.

\section{R E S U M O}

\section{Objetivo}

Descrever a duração e identificar determinantes do aleitamento materno exclusivo.

\section{Métodos}

Foram utilizados dados da "Pesquisa Nacional de Demografia e Saúde da Criança e da Mulher 2006". As informações foram obtidas por meio de questionários aplicados por pesquisadores treinados e referem-se à sub-amostra de 1704 crianças com idade inferior a 24 meses. As estimativas do tempo de aleitamento materno exclusivo são apresentadas segundo variáveis socioeconômicas, demográficas e epidemiológicas. Visando produzir estimativas válidas do tempo de aleitamento materno, foram aplicadas curvas do estimador de Kaplan Meier; para identificação dos riscos, foi ajustado um modelo de razão de riscos de Cox.

\section{Resultados}

A mediana do tempo de aleitamento materno exclusivo foi estimada em 60 dias. Compuseram o modelo final de Cox: idade da mãe <20 anos (razão de riscos=1,53, intervalo de confiança 95\%=1,11-1,48), uso de chupeta (razão de riscos=1,53, intervalo de confiança 95\%=1,37-1,71), não residir na Região Sudeste (razão de riscos $=1,22$, intervalo de confiança 95\%=1,07-1,40) e situação socioeconômica (razão de riscos=1,28, intervalo de confiança 95\%=1,06-1,55).

\section{Conclusão}

A utilização do estimador de Kaplan Meier resultou na correção da subestimativa do tempo de aleitamento materno no País quando calculado a partir da metodologia do current status. Os resultados indicam que, apesar dos esforços empreendidos nas últimas décadas para promover o aleitamento no País, o tempo de aleitamento materno exclusivo é ainda metade do recomendado para realização do potencial dessa prática alimentar na promoção da saúde. Um modo de reverter tal situação seria a utilização de atividades continuadas de educação que envolvessem os sistemas de ensino e de saúde e que estivessem associadas à campanhas publicitárias veiculadas na rede de televisão e rádio, dirigidas prioritariamente a mães jovens, com pouca escolaridade, e de baixa renda, identificadas como as de risco aumentado para o desmame precoce.

Termos de indexação: Aleitamento materno. Inquéritos epidemiológicos. Lactente. Fatores de risco. Análise de sobrevida.

\section{INTRODUCTION}

Exclusive Breastfeeding (EB) is defined as the period in which the child receives only breast milk, directly or indirectly, and no other fluid or solid food, except vitamin, mineral and/or medicinal drops or syrups ${ }^{1}$. Breast milk is the best food for the child's growth and development and breastfeeding also benefits the mother. Even though breastfeeding is a natural act, it requires learning. All mothers are capable of breastfeeding, but they need support from health professionals and family members to become self-confident, use appropriate breastfeeding techniques, and prevent and solve breastfeeding difficulties ${ }^{2}$.

There is evidence that EB improves the survival of premature or low-birth-weight children $^{3}$, reduces neonatal mortality by $16.3 \%$ in children breastfed on the first day of life and by $22.3 \%$ in children breastfed in the first hour of life ${ }^{4}$, promotes neural stimuli appropriate for mandibular bone and muscle growth preventing malocclusions caused by underdevelopment ${ }^{5}$, and protects against the diseases common to early childhood, such as diarrhea and respiratory 
diseases ${ }^{6}$. Additionally, the family and community also benefit from the lower annual health costs, which in the United States of America (USA) was of approximately 3.6 billion USD, parents miss fewer workdays, more attention is paid to twins, and the family faces fewer household difficulties associated with child diseases, among others ${ }^{7}$.

According to data from Demographic and Health Surveys (DHS) done in many countries between 1990 and 2000, EB increased by 15\% in developing countries, going from $46 \%$ to $53 \%$ for children under four months of age. For children under six months of age, EB increased from 34\% to $39 \%$, justified by the creation of the BabyFriendly Hospital Initiative (BFHI) in 1991 and the International Code of Marketing of Breast-milk Substitutes ${ }^{8}$. With the publication of the Global Strategy for Infant and Young Child Feeding in 2003, this practice is expected to grow even more.

Analysis of breastfeeding in the last decades shows that it has declined globally due to factors such as the industrialization process that occurred at the end of the XIX Century, women joining the workforce with concomitant production increase, marketing of infant formulas and growing use of infant formulas. In the 1970s, the consequences of early weaning led to global breastfeeding-promotion initiatives. In 1981, Brazil also created promotion strategies, such as the Programa Nacional de Incentivo ao Alimento Materno (PNIAM, National Program to Encourage Breastfeeding), a program marked by intense social mobilization in favor of breastfeeding, and included a maternity leave of 120 days in the Brazilian Constitution of 1988. In 1995, the Ministry of Health published the "Breastfeeding and the Municipalities" document, and in 2007, the "Network Breastfeed Brazil" was created, a strategy for the primary healthcare service to approach breastfeeding". Additionally, the "Brazil Breastfeed and Feed Strategy" was launched in 2012 for the Unified Healthcare System (SUS) to reinforce and encourage breastfeeding and healthy diets for children under two years of age.
Household surveys show that breastfeeding ${ }^{10}$ has been gradually increasing since $1981^{11}$. Surveys of infants done during the 1999 and 2008 vaccination campaigns showed that exclusive breastfeeding increased by one month, going from 23.4 days to 54.1 days ${ }^{12}$.

There are many factors that can lead to unsuccessful EB: socioeconomic, demographic and epidemiological, such as mother being employed $^{13}$, mother's age under 20 years $^{14}$, mother having less than 8 years of formal education ${ }^{15}$, absence of the father in the family structure $^{14,16}$, low socioeconomic status ${ }^{14}$, fewer than six prenatal care visits, baby not staying in the same room as the mother at the hospital ${ }^{17}$, being a first-time mother ${ }^{14,16}$, type of delivery ${ }^{15}$, and nutrition-related factors, such as the use of pacifiers or bottles ${ }^{13,15}$.

Because of the benefits of $E B$ and the different policies and programs implemented in in the country during the last decade that greatly incentivize EB, knowledge about EB epidemiology and factors that hinder or facilitate its practice need periodical update. Considering that population-based studies on the determinants of $E B$ are scarce in Brazil and the relevance of EB in the context of health and planning of public policies, the present analyses intend to provide information to improve the policies and programs in force in the country.

Pesquisa Nacional de Demografia e Saúde da Criança e da Mulher (PNDS, National Demographic and Health Survey of Women and Children $)^{10}$ data were used for assessing the prevalence and determinants of EB in Brazil. Contrary to national population surveys which have a more descriptive character, this type of analysis assessed the association between the duration of EB and different factors to identify the risks associated with early cessation of $E B$ and provide data for pro-EB policies and programs.

\section{METHODS}

The PNDS aimed to describe the profile of Brazilian women of childbearing age and children 
under five years of age. It was sponsored by the Ministry of Health and coordinated by the Population and Society team of the Centro Brasileiro de Análise e Planejamento (CEBRAP, Brazilian Center for Analysis and Planning $)^{10}$. A nationally representative sample of households was selected by complex probability sampling. The sample units were selected in two stages covering five macroregions and including residence location, that is, rural or urban. A total of 14,617 households were studied, totaling 15,575 women aged 15 to 49 years and approximately 5,000 children under five years of age. The PNDS data, methodology and results can be accessed at (http://bvsms.saude.gov.br/bvs/pnds/index.php).

The abovementioned study was a crosssectional population survey, collecting retrospective and current information, done from November 3, 2006 to May 3, 2007. Each stratum consisted of primary units, which were the census tracts, and secondary units, which were the households. The study universe consisted of private households in common or non-special tracts (including slums), selected from ten sampling strata that composed the combination of the five Brazilian geographic macroregions and of urban and rural areas. The study data were collected by two questionnaires and consisted of basic information about the household and its usual residents and detailed information about the target population (women of childbearing age and children under five years of age) in the following areas: reproduction, birth histories, pregnancies, sexuality, breastfeeding, nutrition and use of medications.

The estimated prevalences of factors associated with EB were calculated considering the complex sampling design of the PNDS $2006^{10}$. The data were treated by the statistical software Stata 10.0. Initially, univariate analyses were done, followed by bivariate analyses.

The age group under 24 months was selected for this study because EB-related information for this group is more reliable since it is less susceptible to recall bias ${ }^{18}$. Hence, children born since 2004 were selected, reflecting the most recent epidemiological scenario of the country. The total subsample of children under 24 months of age consisted of 1,902 infants.

Exclusive breastfeeding data were collected by two questions. Duration of EB was determined by analyzing the data with $E B$ duration of six months (180 days) or less. Twins were excluded from the sample because they require a different breastfeeding process, since two or more newborns are breastfed by a single mother. Only the youngest child of women with more than one child was studied since recall accuracy diminishes with the child's age ${ }^{11}$. The final subsample of the present study consisted of 1,704 infants, enough to obtain good estimate accuracy and reduce chance in the study associations. Thus, whenever the total $\mathrm{n}$ for any variable is below 1,704 , it is because information was not available for the variable.

Duration of EB was described by survival analysis by Kaplan-Meier estimator curves, considering time as the current age of the child and $E B$ as a binary variable (yes or no for $E B$ ), and assuming weaning as the final event (failure) of the analysis. For the children who were still being exclusively breastfed ( $n=249$ or $14.61 \%)$ at the time of the interview, the age of the child at the time was used as the EB time, and the weaning time of this child was considered a censored data in the EB survival analysis. Additionally, one day of breastfeeding was attributed to all children who were not breastfed ( $n=89$ or $5.22 \%$ ).

The logrank test was used for determining which variables were statistically significant in the bivariate analysis and the medians of each variable that could be associated with the duration of EB were calculated. For the multivariate analysis of the variables associated with duration of EB, Cox proportional Hazards Models were fitted, calculating the Hazard Rates (HR) and 95\% confidence intervals. All variables with $p<0.20$ in the bivariate analyses were considered for fitting the final models. Confounding factors or effect modifiers were not identified in the analysis of 
interaction among the independent variables. The variables that remained in the final model were those with a statistical significance below $5 \%$ $(p<0.05)$.

The selection of the study variables considered factors related to the mother, child, health service access profile, and socioeconomic level reported by the literature as being associated with EB. The study variables with possible association were: age of the child in months, gender, birth weight in grams, whether the child stayed in the mother's room after birth, hospitalizations during the neonatal period, mother's age in years, mother's education level in years, presence of a partner in the household, pregnancy planning status, number of prenatal care visits, type of delivery, family socioeconomic status, mother's employment status, EB-related data and use of pacifiers.

Household income was expressed as the number of minimum salaries at the time the PNDS 2006 data were collected. The socioeconomic class of the families was determined by the Brazilian Socioeconomic Classification Criterion from the Associação Brasileira de Estudos Populacionais (ABEP, Brazilian Association of Population Studies), used in the PNDS of $2006^{19}$. The determination is based on the number of certain assets in the household and education level of the family head.

The study was approved by the Universidade Federal de São Paulo Research Ethics Committee under protocol number 0055/11 on January 28, 2011.

\section{RESULTS}

Table 1 shows the median EB durations and associations with independent variables. The median EB duration was 60 days, the $25^{\text {th }}$ percentile was 5 days and the $75^{\text {th }}$ percentile was 150 days. Both the urban and rural regions had median EB durations of 60 days. EB lasted longer in the southeastern region than in the rest of the country. The $25^{\text {th }}$ percentile for the southeastern region was 18.5 days and for the rest of the country, 5 days. In the southern region, the $75^{\text {th }}$ percentile was 120 days, less than that for the rest of the country, which was 150 days.

Socioeconomic, demographic and epidemiological characteristics: The sample consisted of 1,704 children aged 0 to 24 months, where $52.7 \%$ were males. Roughly $70.0 \%$ of the families had a per capita income of less than one minimum salary ( $R \$ 350.00)$. More than half $(52.0 \%)$ the study mothers had less than 8 years of formal education and $19.6 \%$ of them were aged less than 20 years.

Pregnancy, delivery and health conditions: Almost half ( $45.3 \%$ ) the deliveries were cesareans and $47.9 \%$ of the pregnancies were unwanted or mistimed. Most (83.3\%) women attended fewer than six prenatal care visits. Roughly $50.0 \%$ of the study mothers were first-time mothers and $77.4 \%$ of the children had skin-to-skin contact with their mothers in the first half hour of life. Nearly all children (95.2\%) were discharged from the hospital together with their mothers and $4.9 \%$ of them had low birth weight $(<2,500 \mathrm{~g})$.

Nutrition: Almost half (39.0\%) the children were using pacifiers at the time of the interview and more than half (62.4\%) were breastfed within the first hour of life.

The variables in Table 1 with $p<0.20$ in the logrank test, making them eligible for adjustment for multivariate analysis, were: not residing in the southeastern ( $H R=1.13, p=0.065)$ and southern (HR=1.11, $p=0.134)$ macroregions, socioeconomic class ( $H R=1.19, p=0.070)$, mother's age lower than 20 years $(H R=1.29, p=0.001)$, mother with less than 8 years of formal education $(H R=1.13$, $p=0.018)$, pregnancy planning status $(H R=1.07$, $p=0.188)$, fewer than six prenatal care visits ( $H R=1.09, p=0.188)$, whether child had skin-toskin contact with mother $(H R=1.13, p=0.051)$, child being breastfed within the first hour of life $(H R=1.12, p=0.037)$ and use of pacifier $(H R=1.48$, $p=0.000$ ).

Figure 1 shows the Kaplan-Meier estimator curves for the variables with a significant $p$ value 
264 | S WARKENTIN et al.

Table 1. Duration of exclusive breastfeeding for children under 2 years of age according to the study independent variables. Brazil, 2006.

\begin{tabular}{|c|c|c|c|c|c|c|c|}
\hline Variable & Categories & $n$ & $\%$ & $\mathrm{P} 25$ & Median & P75 & $p$ \\
\hline \multicolumn{8}{|l|}{$\begin{array}{l}\text { Socioeconomic, demographic and } \\
\text { epidemiological characteristics }\end{array}$} \\
\hline Brazil & Yes & 1,704 & 100.0 & 5.0 & 60 & 150.0 & - \\
\hline Residence location & $\begin{array}{l}\text { Rural } \\
\text { Urban }\end{array}$ & $\begin{array}{c}563 \\
1,141\end{array}$ & $\begin{array}{l}18.3 \\
81.8\end{array}$ & $\begin{array}{l}5.0 \\
5.0\end{array}$ & $\begin{array}{l}60 \\
60\end{array}$ & $\begin{array}{l}150.0 \\
150.0\end{array}$ & 0.545 \\
\hline North & $\begin{array}{l}\text { Yes } \\
\text { Country }\end{array}$ & $\begin{array}{c}390 \\
1,314\end{array}$ & $\begin{array}{l}11.0 \\
89.0\end{array}$ & $\begin{array}{l}4.0 \\
6.0\end{array}$ & $\begin{array}{l}60 \\
60\end{array}$ & $\begin{array}{l}150.0 \\
150.0\end{array}$ & 0.230 \\
\hline Northeast & $\begin{array}{l}\text { Yes } \\
\text { Country }\end{array}$ & $\begin{array}{c}318 \\
1,386\end{array}$ & $\begin{array}{l}26.7 \\
73.3\end{array}$ & $\begin{array}{l}8.0 \\
5.0\end{array}$ & $\begin{array}{l}60 \\
60\end{array}$ & $\begin{array}{l}120.0 \\
150.0\end{array}$ & 0.722 \\
\hline Southeast & $\begin{array}{l}\text { Yes } \\
\text { Country }\end{array}$ & $\begin{array}{c}312 \\
1,392\end{array}$ & $\begin{array}{l}41.5 \\
58.5\end{array}$ & $\begin{array}{c}18.5 \\
5.0\end{array}$ & $\begin{array}{l}90 \\
60\end{array}$ & $\begin{array}{l}150.0 \\
120.0\end{array}$ & 0.023 \\
\hline South & $\begin{array}{l}\text { Yes } \\
\text { Country }\end{array}$ & $\begin{array}{c}317 \\
1,387\end{array}$ & $\begin{array}{l}12.2 \\
87.8\end{array}$ & $\begin{array}{l}7.0 \\
5.0\end{array}$ & $\begin{array}{l}60 \\
60\end{array}$ & $\begin{array}{l}120.0 \\
150.0\end{array}$ & 0.069 \\
\hline Central-West & $\begin{array}{l}\text { Yes } \\
\text { Country }\end{array}$ & $\begin{array}{c}367 \\
1,337\end{array}$ & $\begin{array}{r}8.6 \\
91.4\end{array}$ & $\begin{array}{l}3.0 \\
7.0\end{array}$ & $\begin{array}{l}60 \\
60\end{array}$ & $\begin{array}{l}150.0 \\
150.0\end{array}$ & 0.720 \\
\hline Gender & $\begin{array}{l}\text { Female } \\
\text { Male }\end{array}$ & $\begin{array}{l}805 \\
899\end{array}$ & $\begin{array}{l}47.3 \\
52.7\end{array}$ & $\begin{array}{l}5.0 \\
5.0\end{array}$ & $\begin{array}{l}60 \\
60\end{array}$ & $\begin{array}{l}120.0 \\
150.0\end{array}$ & 0.318 \\
\hline Socioeconomic class (ABEP) & $\begin{array}{l}A+B+C \\
D+E\end{array}$ & $\begin{array}{c}143 \\
1,561\end{array}$ & $\begin{array}{r}8.2 \\
91.7\end{array}$ & $\begin{array}{l}7.0 \\
5.0\end{array}$ & $\begin{array}{l}90 \\
60\end{array}$ & $\begin{array}{l}150.0 \\
150.0\end{array}$ & 0.024 \\
\hline Per capita income under 1 salary $(\mathrm{R} \$ 350.00)$ & $\begin{array}{l}\text { Yes } \\
\text { No }\end{array}$ & $\begin{array}{c}1,266 \\
438\end{array}$ & $\begin{array}{l}72.8 \\
27.2\end{array}$ & $\begin{array}{l}5.0 \\
5.0\end{array}$ & $\begin{array}{l}60 \\
60\end{array}$ & $\begin{array}{l}150.0 \\
150.0\end{array}$ & 0.593 \\
\hline Mother's age ( $<20$ years) & $\begin{array}{l}\text { Yes } \\
\text { No }\end{array}$ & $\begin{array}{c}267 \\
1,437\end{array}$ & $\begin{array}{l}19.6 \\
80.4\end{array}$ & $\begin{array}{l}3.0 \\
7.0\end{array}$ & $\begin{array}{l}30 \\
60\end{array}$ & $\begin{array}{l}120.0 \\
150.0\end{array}$ & 0.000 \\
\hline Mother's education level ( $\leq 8$ years) & $\begin{array}{l}\text { Yes } \\
\text { No }\end{array}$ & $\begin{array}{l}983 \\
721\end{array}$ & $\begin{array}{l}52.0 \\
48.0\end{array}$ & $\begin{array}{l}5.0 \\
6.0\end{array}$ & $\begin{array}{l}60 \\
90\end{array}$ & $\begin{array}{l}120.0 \\
150.0\end{array}$ & 0.003 \\
\hline Mother lives with partner & $\begin{array}{l}\text { Yes } \\
\text { No }\end{array}$ & $\begin{array}{c}1,660 \\
44\end{array}$ & $\begin{array}{r}97.1 \\
2.9\end{array}$ & $\begin{array}{l}5.0 \\
3.5\end{array}$ & $\begin{array}{l}60 \\
45\end{array}$ & $\begin{array}{l}150.0 \\
120.0\end{array}$ & 0.947 \\
\hline Mother is employed & $\begin{array}{l}\text { Yes } \\
\text { No }\end{array}$ & $\begin{array}{c}522 \\
1,182\end{array}$ & $\begin{array}{l}28.2 \\
71.8\end{array}$ & $\begin{array}{l}7.0 \\
5.0\end{array}$ & $\begin{array}{l}60 \\
60\end{array}$ & $\begin{array}{l}120.0 \\
150.0\end{array}$ & 0.763 \\
\hline \multicolumn{8}{|l|}{ Pregnancy and delivery conditions } \\
\hline Wanted pregnancy & $\begin{array}{l}\text { Yes } \\
\text { No }\end{array}$ & $\begin{array}{l}868 \\
836\end{array}$ & $\begin{array}{l}52.1 \\
47.9\end{array}$ & $\begin{array}{l}5.0 \\
6.0\end{array}$ & $\begin{array}{l}60 \\
60\end{array}$ & $\begin{array}{l}150.0 \\
120.0\end{array}$ & 0.105 \\
\hline Prenatal care $<6$ visits & $\begin{array}{l}\text { Yes } \\
\text { No }\end{array}$ & $\begin{array}{c}1,362 \\
342\end{array}$ & $\begin{array}{l}83.3 \\
16.7\end{array}$ & $\begin{array}{l}5.0 \\
5.0\end{array}$ & $\begin{array}{l}60 \\
60\end{array}$ & $\begin{array}{l}150.0 \\
120.0\end{array}$ & 0.106 \\
\hline Type of delivery (cesarean) & $\begin{array}{l}\text { Yes } \\
\text { No }\end{array}$ & $\begin{array}{l}750 \\
953\end{array}$ & $\begin{array}{l}45.3 \\
54.7\end{array}$ & $\begin{array}{l}5.0 \\
6.0\end{array}$ & $\begin{array}{l}60 \\
60\end{array}$ & $\begin{array}{l}150.0 \\
150.0\end{array}$ & 0.727 \\
\hline First-time mother & $\begin{array}{l}\text { Yes } \\
\text { No }\end{array}$ & $\begin{array}{l}724 \\
980\end{array}$ & $\begin{array}{l}51.7 \\
48.3\end{array}$ & $\begin{array}{l}5.0 \\
6.0\end{array}$ & $\begin{array}{l}60 \\
60\end{array}$ & $\begin{array}{l}120.0 \\
150.0\end{array}$ & 0.218 \\
\hline Low birth weight $(<2.500 \mathrm{~g})$ & $\begin{array}{l}\text { Yes } \\
\text { No }\end{array}$ & $\begin{array}{c}93 \\
1,574\end{array}$ & $\begin{array}{r}4.9 \\
95.1\end{array}$ & $\begin{array}{l}5.0 \\
5.0\end{array}$ & $\begin{array}{l}60 \\
60\end{array}$ & $\begin{array}{l}120.0 \\
150.0\end{array}$ & 0.230 \\
\hline Skin-to-skin contact in the first half hour & $\begin{array}{l}\text { Yes } \\
\text { No }\end{array}$ & $\begin{array}{c}1,322 \\
374\end{array}$ & $\begin{array}{l}77.4 \\
22.6\end{array}$ & $\begin{array}{l}6.0 \\
4.0\end{array}$ & $\begin{array}{l}60 \\
60\end{array}$ & $\begin{array}{l}150.0 \\
120.0\end{array}$ & 0.017 \\
\hline Child stayed in hospital after delivery & $\begin{array}{l}\text { Yes } \\
\text { No }\end{array}$ & $\begin{array}{c}67 \\
1,592\end{array}$ & $\begin{array}{r}4.8 \\
95.2\end{array}$ & $\begin{array}{l}2.0 \\
6.0\end{array}$ & $\begin{array}{l}30 \\
60\end{array}$ & $\begin{array}{l}120.0 \\
150.0\end{array}$ & 0.186 \\
\hline $\begin{array}{l}\text { Child stayed at the mother's room after } \\
\text { delivery feeding }\end{array}$ & $\begin{array}{l}\text { Yes } \\
\text { No }\end{array}$ & $\begin{array}{c}1,514 \\
145\end{array}$ & $\begin{array}{l}89.8 \\
10.2\end{array}$ & $\begin{array}{l}6.0 \\
5.0\end{array}$ & $\begin{array}{l}60 \\
60\end{array}$ & $\begin{array}{l}150.0 \\
120.0\end{array}$ & 0.705 \\
\hline Child was breastfed in the first half hour after birth & $\begin{array}{l}\text { Yes } \\
\text { No }\end{array}$ & $\begin{array}{c}1,068 \\
634\end{array}$ & $\begin{array}{l}62.4 \\
37.6\end{array}$ & $\begin{array}{l}6.0 \\
5.0\end{array}$ & $\begin{array}{l}60 \\
60\end{array}$ & $\begin{array}{l}150.0 \\
120.0\end{array}$ & 0.011 \\
\hline Use of pacifier & $\begin{array}{l}\text { Yes } \\
\text { No }\end{array}$ & $\begin{array}{c}635 \\
1,058\end{array}$ & $\begin{array}{l}39.0 \\
61.0\end{array}$ & $\begin{array}{l}6.0 \\
5.0\end{array}$ & $\begin{array}{l}60 \\
90\end{array}$ & $\begin{array}{l}120.0 \\
150.0\end{array}$ & 0.000 \\
\hline
\end{tabular}

Note: P: Percentile; ABEP: Associação Brasileira de Estudos Populacionais (Brazilian Association of Population Studies).

$P$-values in bold indicate variables with $p<0.20$. All variables with $p<0.20$ in the bivariate analyses were considered for the adjustment of the final models. 
$(p<0.05)$ that remained in the final Cox model. The four graphs show that children who used pacifiers, whose mothers were less than 20 years of age, who did not live in the southeastern region, and whose socioeconomic class was low had a smaller survival, that is, the proportion of exclusively breastfed children with these risk factors was always smaller than the proportion of children without these risk factors at each point of the 180-day timeline.

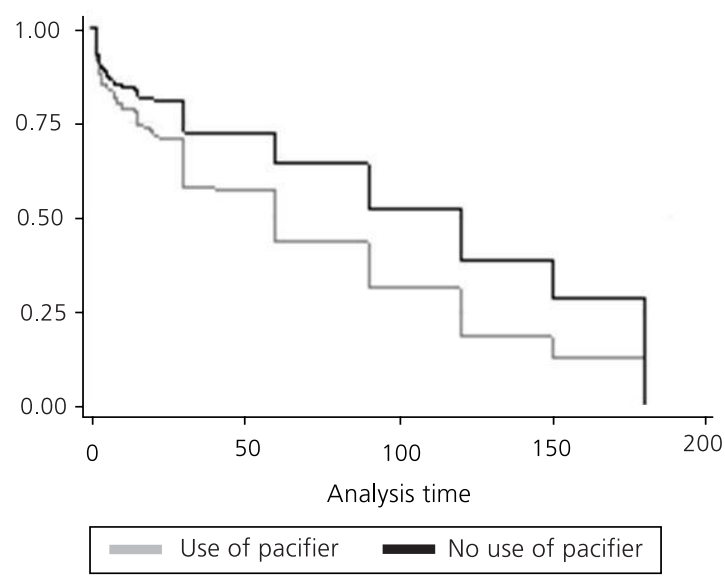

C

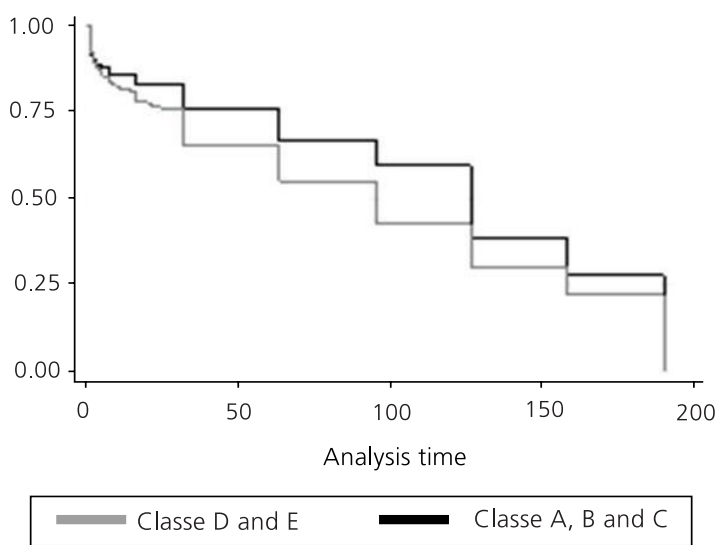

Figure 2 shows the estimates obtained by the Cox regression model using this set of variables. The hazard rates and their respective 95\% confidence intervals are shown for each statistically significant $(p<0.05)$ risk factor. The use of pacifier, mother aged less than 20 years, not residing in the southeastern region and belonging to the low socioeconomic class increase the risk of early weaning independently by $53 \%, 28 \%$, $22 \%$ and $28 \%$, respectively.

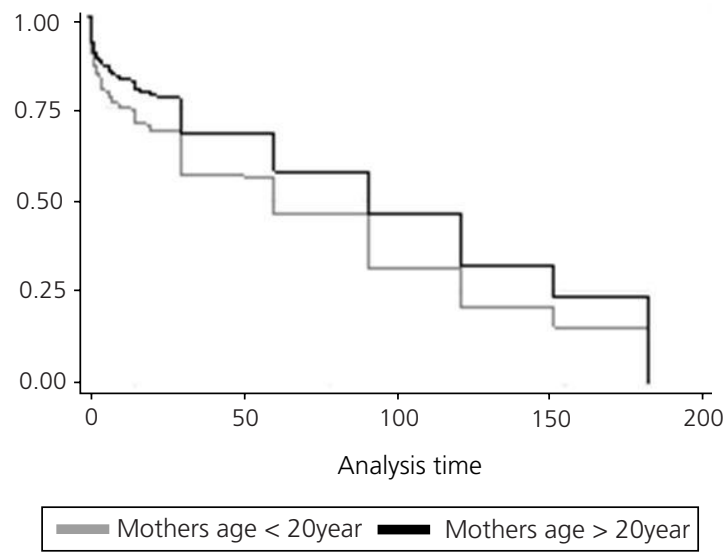

D

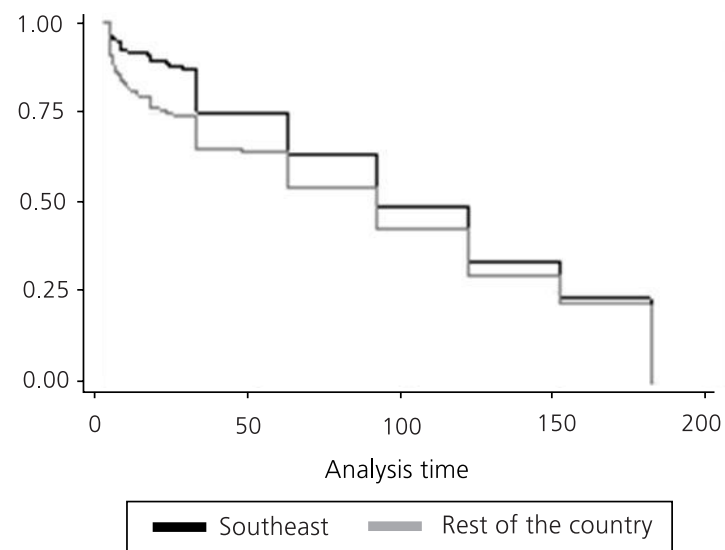

Figure 1. Kaplan-Meier estimated survival curve for the four variables included in the Cox model for children under two years of age analyzed by the Pesquisa Nacional de Demografia e Saúde da Criança e da Mulher (PNDS, National Demographic and Health Survey on Women and Children). Brazil, 2006. 
266 | S WARKENTIN et al.

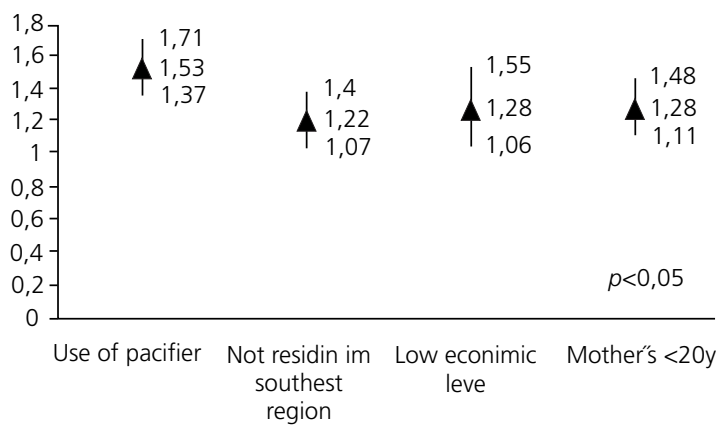

Figure 2. Hazard Rates (HR) and the respective $95 \%$ confidence intervals for weaning before the sixth month of age for children under two years of age analyzed by the Pesquisa Nacional de Demografia e Saúde da Criança e da Mulher (PNDS, National Demographic and Health Survey on Women and Children). Brazil, 2006

Note: *Model fitted for living in the southern macroregion, attending fewer than 6 prenatal care visits, pregnancy planning status, mother having 8 years or less of formal education, skin-to-skin contact with mother within the first half hour of life, child's gender, and breastfeeding in the first half hour of life.

\section{DISCUSSION}

Although the survey was done in 2006/ 2007, the fact that only the children under two years of age were included makes the sample representative of the live infants with fixed residence in the country born between 2004 and 2007. Accordingly, these results reflect the situation of EB six years ago, which is the most recent information available for the country.

Including only children aged less than 24 months at the time of the field study reduces the recall bias since the weaning-related information of this group is more recent than that of older groups, such as those younger than 60 months ${ }^{18}$.

The median EB duration for the children aged less than two years in the present study was 60 days, which is shorter than that found by Bernardi et al. ${ }^{20}$ using a similar methodology in a sample of 2857 infants from the municipality of Campinas (SP), Brazil, in 2004, and shorter than that found by a recent study of children born in baby-friendly hospitals in Teresina (PI), Brazil, where the median EB duration was 98 days ${ }^{21}$.
When the entire PNDS ${ }^{10}$ sample of children aged less than 5 years is considered, the median EB duration was only 1.4 months, or 42 days. The smaller duration found by this analysis may be attributed to current status methodology, which underestimates $\mathrm{EB}$ duration by equalizing $\mathrm{EB}$ duration to the child's age at the time of the survey, even though many of the study children will continue to be exclusively breastfed for varying lengths of time ${ }^{3,22}$. The present analysis used the EB duration reported by the mother during the interview, not the breastfeeding status of the child then. For the estimator construction, only the children who were already being weaned were considered study events, those who were still being EB were censored. The children with EB duration in excess of 180 days were excluded from the sample since this is considered another type of feeding error.

The results of the present study show that children living in the southeastern macroregion have longer EB duration. This finding is similar to that of Venâncio et al. ${ }^{12}$ who found that duration of EB is greatest in the Northern region, followed by the central-western region, southern region, and finally, southeastern region. These differences may stem from the different sampling procedures, since Venâncio et al. ${ }^{12}$ included only children aged less than one year who were vaccinated during a combination-vaccine campaign. The limitation of this sampling procedure is the non-representation of children who are not vaccinated. However, it has the important advantage of estimating the breastfeeding prevalences of different locations, which can be used for planning and implementing public actions and policies that promote and encourage breastfeeding.

Comparison of the socioeconomic status of the study mothers showed that mothers of lower socioeconomic classes tend to breastfeed exclusively for shorter periods because they ignore the benefits of this practice. This finding is in agreement with those of other studies ${ }^{14,20}$.

In the present study, $62.4 \%(n=1068)$ of the children were breastfed within the first hour 
of life, similar to the $67.7 \%$ found by Venâncio et al. ${ }^{12}$. These two percentages exceed the $43.0 \%$ found by the PNDS, which considered the entire sample of children aged less than 5 years ${ }^{10}$. This difference may stem from the fact that the present study analyzes a subsample of children aged less than 2 years and from the possible recall bias of the mothers of children aged more than 2 years who might have underestimated EB duration. EB practices may also have changed over the years, where older children were exclusively breastfed for shorter periods than younger children at the time of the survey. Like the present study, another study also found that breastfeeding within the first hour of life promotes EB in children born in baby-friendly hospitals when compared with those who were not breastfed within the first hour of life ${ }^{23}$. Breastfeeding right after birth strengthens the mother-child bond, increases breastfeeding duration and reduces neonatal mortality ${ }^{22}$.

The study results show that young mothers and unwanted pregnancies are strongly associated with shorter EB durations, which was also found by Haughton et al. ${ }^{24}$ while studying 155 children covered by a North American nutritional supplementation program (WIC Program).

In agreement with the study by Bernardi et al. ${ }^{20}$, early weaning was associated with lower maternal age and education level. These characteristics are common among adolescent mothers who are often also single and struggle to support themselves and their children. Their insecurity prevents them from feeding the baby correctly and the lack of support from their mothers and family members results in shorter EB durations ${ }^{17}$. Other studies have also evidenced that low maternal education level contributes to early weaning ${ }^{25,26}$.

In addition to the present study, other studies have also found that low birth weight is associated with early weaning ${ }^{27,28}$. One of these studies included a sample of children who were vaccinated in the vaccination campaign of 2001 and analyzed the individual and contextual factors that may have been associated with EB in more than 30 thousand children of 111 municipalities in the state of São Paulo ${ }^{28}$. Shorter EB durations in low-birth-weight children may stem from sucking difficulties since many are also preterm.

It is important to emphasize that six or more prenatal care visits had a protective effect on EB among the study mothers ( $p=0.045$ ). There are divergences in the literature regarding the influence of prenatal care on breastfeeding. Faleiros' et al. ${ }^{17}$ review found that prenatal care efficiently allows greater access to information on the benefits of $E B$, preventing early weaning. On the other hand, Haughton et al..$^{24}$ did not find association between the knowledge gained during pregnancy and breastfeeding success.

It is clear that the use of a pacifier has the greatest influence on early weaning. This finding is in agreement with those of other studies in the country ${ }^{17,20,26}$. The association between the use of a pacifier and an increased risk of early weaning has already been proven, justifying the country's intervention to discourage its use. In addition to informing the risks associated with using a pacifier, health professionals need to be trained to provide support to mothers during the first six months after delivery. Specific strategies for reducing the use of pacifiers need testing but there is still very little about this subject in the literature ${ }^{15}$.

The use of a pacifier may be regarded as a marker of breastfeeding difficulties. Pacifiers may conceal maternal problems, such as anxiety and insecurity, which have a negative impact on EB. Additionally, the use of a pacifier reduces the suction reflex, reducing the number and duration of breastfeedings and the local stimulus for milk secretion, leading to the progressive discontinuation of breastfeeding. Another hypothesis of the negative effect of pacifiers is the mechanism of nipple confusion ${ }^{29}$.

A qualitative study on mothers' knowledge and practices shows that they are aware of the benefits of EB for them and the baby, but they hardly know what to do when the baby refuses 
268 | S WARKENTIN et al.

to breastfeed or about the misconceptions that their milk is weak or inadequate ${ }^{18}$. These reports lead to the understanding that contemporary women have a more anxious and tense experience with feeding the child, and should receive more support from health professionals to manage to fully breastfeed.

Cross-sectional studies, such as the PNDS, include infants that survived, so children who were born in unfavorable conditions or who were stricken by common childhood diseases and died do not compose the sample. Hence, survival bias was present in this study. Since early weaning increases the risk of death, it is possible that the herein estimated EB durations and associations have consequently been underestimated ${ }^{30}$.

\section{CONCLUSION}

The results of this study show that the use of epidemiological restriction strategies that attempt to avoid biases associated with statistical election techniques for describing time-related events generated more accurate estimated prevalences of early weaning from more recent data with national representativeness. The multivariate model identified and quantified the independent risks of early weaning, an important bit of information for planning policies and programs. These results add to those generated by the first analysis of the 2006 survey that aimed to contribute to the discussion about the international recommendations for analyzing questionable data and to the potential of using more accurate techniques when accurate data is available.

\section{ACKNOWLENDGEMENTS}

Sarah Warkentin and Kelly de Jesus Viana received a master's scholarship from Coordenação de Aperfeiçoamento de Pessoal de Nível Superior, José Augusto de Aguiar Carrazedo Taddei received a scholarship from Conselho Nacional de Desenvolvimento Científico e Tecnológico (CNPq, National Council for Scientific and Technological Development).

\section{CONTRIBUTORS}

SWARKENTIN was responsible for data analysis and writing the article. JAAC TADDEI was coresponsible for conceiving the project and reviewing the article. KJ VIANA was co-responsible for analyzing the data and writing the article. FAB COLUGNATI was co-responsible for conceiving the project and reviewing the article.

\section{REFERE N C E S}

1. Brasil. Ministério da Saúde. Guia alimentar para crianças menores de 2 anos. Brasília: MS; 2002.

2. World Health Organization. The optimal duration of exclusive breastfeeding. Geneva: WHO; 2001. Note for the press n.7.

3. Braga DF, Machado MMT, Bosi MLM. Amamentação exclusiva de recém-nascidos prematuros: percepções e experiências de lactentes usuárias de um serviço público especializado. Rev Nutr. 2008; 21(3):293-302. doi: 10.1590/S1415-52732008000 300004.

4. Edmond KM, Zandoh C, Quigley MA, AmengaEtego S, Owusu-Agyei S, Kirkwood BR. Delayed breastfeeding initiation increases risk of neonatal mortality. Pediatrics. 2006; 117(3):380-6. doi: 10.1542/peds.2005-1496.

5. Cavalcanti-Leite A, Medeiros-Bezerra PK, Moura C. Aleitamento natural, aleitamento artificial, hábitos de sucção e maloclusões em pré-escolares brasileiros. Rev Salud Pública. 2007; 9(2):194-204. doi: 10.1590/S0124-00642007000200004.

6. Bernardi JR, Gama CM, Vitolo MR. Impacto de um programa de atualização em alimentação infantil em unidades de saúde na prática do aleitamento materno e na ocorrência de morbidade. Cad Saúde Pública. 2011; 27(6):1213-22. doi: 10.1590/S0102311X2011000600018.

7. American Academy of Pediatrics. Section on breastfeeding: Breastfeeding and the use of human milk. Pediatrics. 2005; 115(2):2004-491. doi: 10.15 42/peds.2004-2491.

8. Labbok MH, Wardlaw T, Blanc A, Clark D, Terreri $\mathrm{N}$. Trends in exclusive breastfeeding: Findings from the 1990s. J Hum Lact. 2006; 22(3):272-6. doi: $10.1177 / 0890334405279256$.

9. Venancio SI, Nogueira-Martins MCF, Giugliani ERJ. Reflexões sobre a trajetória do aleitamento materno no Brasil e suas interfaces com o movimento pela humanização do parto e nascimento e com a política nacional de humanização. Rev Tempus Actas Saúde Coletiva. 2010; 4(4):129-41. 
10. Brasil. Ministério da Saúde. Pesquisa nacional de demografia e saúde da criança e da mulher: PNDS 2006. Brasília: MS; 2008. [Relatório da Pesquisa].

11. Barros FC, Victora CG. Breastfeeding and diarrhea in Brazilian children. Pelotas: UFP; 1990.

12. Venâncio SI, Escuder MML, Saldiva SRDM, Giugliani ERJ. Breastfeeding practice in the Brazilian capital cities and the Federal District: Current status and advances. J Pediatr. 2010; 86(4):317-24. doi: 10.22 23/JPED.2016.

13. Franco SC, Nascimento MBR, Reis MAM, Issler $H$, Grisi SJFE. Aleitamento materno exclusivo em lactentes atendidos na rede pública do município de Joinville, Santa Catarina, Brasil. Rev Bras Saúde Matern Infant. 2008; 8(3):291-7. doi: 10.1590/ S1519-38292008000300008.

14. Carrascoza KC, Costa Júnior AL, Moareas ABA. Fatores que influenciam o desmame precoce e a extensão do aleitamento materno. Estud Psicol. 2005; 22(4):433-40. doi: 10.1590/50103-166×200 5000400011 .

15. Parizoto GM, Parada CMGL, Venâcio SI, Cavalhaes MABL. Trends and patterns of exclusive breastfeeding for under-6-month-old children. J Pediatr. 2009; 85(3):201-8. doi: 10.1590/S0021-75572009000 300004.

16. Agboado G, Michel E, Jackson E, Verma A. Factors associated with breastfeeding cessation in nursing mothers in a peer support programme in Eastern Lancashire. BMC Pediatrics. 2010; 10(3):1-10. doi: 10.1186/1471-2431-10-3.

17. Faleiros FTV, Trezza EMC, Carandina L. Aleitamento materno: fatores de influência na sua decisão e duração. Rev Nutr. 2006; 19(5):623-30. doi: 10.15 90/S1415-52732006000500010.

18. Oliveira O, Taddei JAAC. Efeito dos vieses de sobrevivência nas prevalências da desnutrição em crianças no sexto ano de vida. Brasil - PNSN, 1989. Cad Saúde Pública. 1998; 14(3):493-9. doi: 10.15 90/S0102-311X1998000300005.

19. Associação Brasileira de Empresas de Pesquisa. Dados com base no levantamento sócio econômico 2006 e 2007 - IBOPE. São Paulo: ABEP; 2010 (acesso 2011 nov 10). Disponível em: <www.abep.org>.

20. Bernardi JLD, Jordão RE, Barros Filho AA. Fatores associados à duração mediana do aleitamento materno em lactentes nascidos em municípios do estado de São Paulo. Rev Nutr. 2009; 22(6):867-78. doi: 10.1590/S1415-52732009000600008.

21. Ramos CV, Almeida JAG, Saldiva SRDM, Pereira LMR, Alberto NSMC, Teles JBM, et al. Prevalência do aleitamento materno exclusivo e os fatores à ele associados em crianças nascidas nos Hospitais Amigos da Criança de Teresina - PI. Epidemiol Serv Saúde. 2010; 19(2):115-24.

22. Boccolini CS, Carvalho ML, Oliveira MIC, Vasconcellos AGG. Fatores associados à amamentação na primeira hora de vida. Rev Saúde Pública. 2011; 45(1): 69-78. doi: 10.1590/S0034-89102010005000051.

23. Notzon F. Trends in infant feeding in developing countries. Pediatrics. 1984; 74(4):648-66.

24. Haughton J, Gregorio D, Pérez-Escamilla R. Factors associated with breastfeeding duration among connecticut special supplemental nutrition program for Women, Infants, and Children (WIC) participants. J Hum Lact. 2010; 26(3):266-73. doi: 10.1177/0890334410365067.

25. Lutter CK, Chaparro CM, Grummer-Strawn LM. Increases in breastfeeding in Latin America and the Caribbean: An analysis of equity. Health Policy Plann. 2011; 26(3):257-65. doi: 10.1093/heapol/ czq046.

26. Nascimento MBR, Reis MAM, Franco SC, Issler $H$, Ferraro AA, Grisi SJFE. Exclusive breastfeeding in Southern Brazil: Prevalence and associated factors. Breastfeeding Med. 2010; 5(2):79-85. doi:10.1089/ bfm.2009.0008.

27. Koosha A, Hashemifesharaki R, Mousavinasab N. Breast-feeding patterns and factors determining exclusive breast-feeding. Singapore Med J. 2008; 49(12):1002-06.

28. Venancio SI, Monteiro CA. Individual and contextual determinants of exclusive breastfeeding in São Paulo, Brazil: A multilevel analysis. Public Health Nutr. 2006; 9(1):40-6. doi: 10.1079/PHN2005760.

29. Lamounier JA. O efeito de bicos e chupetas no aleitamento materno. J Pediatr. 2003; 79(4):284-6. doi: 10.1590/S0021-75572003000400004.

30. Szklo M, Nieto FJ. Epidemiology: Beyond the basics. $2^{\text {th }}$ ed. Carolina do Norte: Aspen; 2000.

Received on: 26/7/2012

Final version on: 10/12/2012

Approved on: 10/1/2013 
